\title{
ДОКАЗОВЕ ДОСЛІДЖЕННЯ ОЦІНКИ ПІСЛЯОПЕРАЦІЙНОГО БОЛЮ У ДІТЕЙ
}

\author{
Ю. В. Іванович, М. І. Кінаш \\ Львівська обласна дитяча клінічна лікарня “ОХМАТДИТ» \\ ДВНЗ «Тернопільський державний медичний університет \\ імені І. Я. Горбачевського МОЗ Украӥни"
}

У статті подано результати спостережень за вираженістю післяопераційного болю у дітей. Проаналізовано оцінку вираженості болю дитиною, медичними сестрами та батьками.

\section{EVIDENCE-BASED RESEARCH ON THE EVALUATION OF POST-OPERATIVE PAIN IN CHILDREN}

\author{
Y. V. Ivanovych, M. I. Kinash \\ Lviv Oblast Children's Clinical Hospital "OKHMATDYT» \\ I. Horbachevsky Ternopil State Medical University
}

The article presents the results of observations of postoperative pain in children. The differences in the assessment of pain between the child and the nurses and parents are analyzed.

Вступ. Біль - це симптом гострих і хронічних захворювань, який включає механізми формування емоцій, моторні, гуморальні і гемодинамічні прояви, в цілому ідентичні комплексу стрес-реакції на несприятливі дії зовнішнього чи внутрішнього середовища. Оцінка вираженості болю має вирішальне значення для ефективного управління болем. Медичні сестри займають визначне місце в керуванні болем та створенні найкомфортніших умов для його перенесення, оскільки вони найбільше контактують з дитиною та ії сім'єю в лікарні. Якщо біль ефективно не лікується, у дітей це може спричинити тривалі фізичні та психологічні розлади.

Мета дослідження: навчити пацієнтів та їхніх родичів правильно оцінювати вираженість болю та інтерпретувати його за допомогою шкали FLACC та шкали VAS. З'ясувати відмінності в оцінці вираженості болю дитиною, медичними сестрами та батьками, визначити надійність цих шкал у використанні.

Основна частина. Під спостереженням перебувало 38 пацієнтів віком від 3 місяців до 17 років із відсутніми неврологічними порушеннями, які перебували на стаціонарному лікуванні у відділенні інтенсивної терапії Львівської обласної дитячої клінічної лікарні «ОХМАТДИТ». Серед обстежених переважали хлоп-

(C) Ю. В. Іванович, М. І. Кінаш, 2018 чики - 27 (71,1\%), дівчатка становили 11 (28,9%) осіб. У віковій категорії до 7 років (І група) взяли участь 19 (50,0 \%) обстежуваних. Серед них 8 (42,1\%) дівчаток та 11 (57,9 \%) хлопчиків. У категорії від 7 до 18 років (II група) також було 19 (50,0 \%) дітей. Серед них переважали хлопчики 16 (84,2 \%), дівчатка становили 15,8 \%. Пацієнти отримували різні планові операційні втручання (хірургічні, урологічні, ортопедичні, отоларингічні).

Батькам пацієнтів та медичним сестрам були надані анкети з детальною інформацією, які містили дві валідні шкали для оцінки вираженості болю - FLACC та VAS, а також вік, стать, місце проживання дитини.

Шкала FLACC - це інструмент для оцінки вираженості післяопераційного болю у немовлят та дітей молодшого віку. У ній проаналізовано п'ять критеріїв: вираз обличчя, положення ніг, рухова активність, інтенсивність плачу і здатність до заспокоєння. Шкала FLACC призначена для дітей віком від 2 місяців до 7 років (табл. 1) [1].

VAS - візуально-аналогова шкала є простою у використанні, що дозволяє швидко і об'єктивно визначити рівень суб'єктивних больових відчуттів. Використовуючи лінійну шкалу, дитина вказує на інтенсивність больових відчуттів (рис. 1). 
Таблиця 1. Оцінка болю за шкалою FLACC у дітей від 2 місяців до 7 років

\begin{tabular}{|l|l|c|}
\hline \multicolumn{1}{|c|}{ Параметри } & \multicolumn{1}{|c|}{ Характеристика } & Бали \\
\hline \multirow{5}{*}{ Обличчя } & Нормальний вираз обличчя або посмішка & 0 \\
\cline { 2 - 3 } & Невдоволений, насуплює брови, відсутність інтересу до оточення & 1 \\
\cline { 2 - 3 } & Часте або постійне тремтіння підборіддя, стискає зуби & 2 \\
\hline \multirow{5}{*}{ Ноги } & Нормальне положення, розслаблений & 0 \\
\cline { 2 - 3 } & Не може знайти зручного положення, неспокійний, напружений & 1 \\
\cline { 2 - 3 } & Брикання або піднімання (приведення) ніг & 2 \\
\hline \multirow{5}{*}{ Рухи } & Лежить спокійно, положення нормальне, легко рухається & 0 \\
\cline { 2 - 3 } & Корчиться, рухається вперед і назад, напружений & 1 \\
\cline { 2 - 3 } & Вигинається дугою, смикається & 2 \\
\hline \multirow{5}{*}{ Плач } & Не має плачу (коли спить і коли активний) & 1 \\
\cline { 2 - 3 } & Стогне або хникає, час від часу скиглить & 2 \\
\cline { 2 - 3 } & Довго плаче, кричить або схлипує, часто скаржиться & 0 \\
\hline \multirow{2}{*}{$\begin{array}{l}\text { Можливість за- } \\
\text { спокоїти }\end{array}$} & Задоволений, спокійний & 1 \\
\cline { 2 - 3 } & Заспокоюєтся від дотику, обіймів або розмови, можна відвернути увагу & 2 \\
\cline { 2 - 3 } & Важко заспокоїти & 2 \\
\hline
\end{tabular}

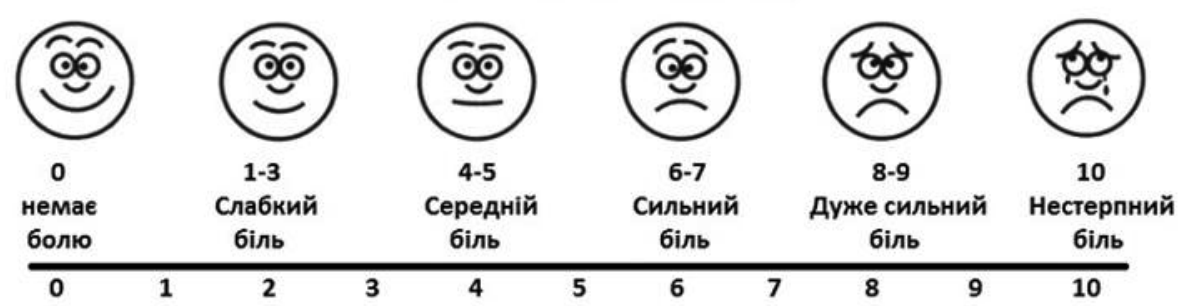

PUс. 1. Шкала VAS для дітей віком від 7 до 18 років.

Існують різні модифікації VAS із можливими градаціями: 0-10 або 0-100. Ми застосовували градацію шкали від 0 до 10 балів. Шкалу VAS використовували для дітей віком від 8 до 18 років. Діти старше семи років були ознайомлені та проінформовані зі шкалою VAS. Батьки пацієнтів та медичні сестри також були проінформованими щодо користування цими шкалами для оцінки вираженості болю [2].

Анкети містили значення результатів таблиць оцінювання, де 0 балів - дитина не відчуває болю, їй комфортно, 1-3 бали - слабкий біль, легкий дискомфорт, 4-6 балів - помірний біль, дискомфорт, 7-10 балів сильний біль. Оцінювати вираженість болю починали після повного пробудження пацієнта (через 40-60 хв після операційного втручання) в післяопераційних палатах. Усі дані були занесені в анкети.

Дітям, які перебували під нашим спостереженням, проводили аденотомію у 26,3 \% випадків, тонзилектомію у 2,63\%, видалення дермоїдної кісти яєчника у 2,6 \%, стороннього тіла в долоні у 2,6 \%, ушивання пахових гриж у 7,9 \% пацієнтів, операційне втручання з приводу металоостеосинтезу відзначали в 31,6 \%, гіпоспадії - у 2,6 \% осіб, лівобічного варикоцеле - у 7,9 \%, гідронефрозу - в 5,3 \%, фімозу та крипторхізму, відповідно, у 2,6 та 5,3 \%, з приводу водянки лівого яєчка в 2,6 \% обстежуваних. Оцінки вираженості болю були задокументовані для всіх пацієнтів у анкетах.

У 19 (50,0 \%) дітей біль був відсутній, 0 балів. Це пацієнти, які перенесли операційне втручання з приводу гідронефрозу (10,5 \%), металоостеосинтезу (31,6 \%), крипторхізму (10,5\%), гіпоспадії (5,3\%), лівобічного варикоцеле $(15,8$ \%), видалення дермоїдної кісти яєчника (5,3 \%), стороннього тіла в долоні (5,3 \%), з приводу ушивання пахової грижі (5,3\%) та аденотомії (10,5\%). Серед цих дітей переважали хлопчики старше 7 років (8 хлопчиків, 36,8 \%). У 13 (34,2 \%) осіб відзначали слабкий біль, 1-3 бали. Серед них переважали хлопчики (11 хлопчиків, 84,6 \%) віком 3-17 років. Зокрема, вони перенесли такі операційні втручання, як металоостеосинтез у 38,46 \% випадків, аденотомію у 38,46 \%, тонзилектомію в 7,70 \%, ушивання пахових гриж у 7,70 \%, а також із приводу водянки лівого яєчка в 7,70 \%. У 4 (10,4 \%) хлопчиків 4-6 років виявили помірний біль, 4-6 балів. Цим дітям проводили 
аденотомію, металоостеосинтез, ушивання пахової грижі, усунення фімозу. Ще у 2 (5,2 \%) хворих 1 (2,6 \%) хлопчика 7 років та у 1 (2,6 \%) дівчинки 5 років інтенсивність болю була найбільш виражена, 7-10 балів. Ці діти були оперовані з приводу аденотомії.

За шкалою FLACC не було розбіжностей в оцінках вираженості болю між батьками та медичними сестрами для дітей I групи. Діти II групи за допомогою візуально-аналогової шкали VAS давали достовірні оцінки болю, які також не відрізнялися від даних медичного персоналу.

Висновки. У результаті дослідження не виявлено відмінностей між показниками оцінки болю медичних сестер, батьків та дітей. Більш виражені відчуття болю

\section{СПИСОК ЛІТЕРАТУРИ}

1. Міщук В. Р. Оцінка больового синдрому у дітей. Сучасний стан проблеми / В. Р. Міщук // Медицина неотложных состояний. - 2016. - № 8. - С. 134-139. (сильний біль) превалювали у дітей I групи, 5-7 років, помірний та слабкий біль більш характерний для дітей від 3 до 17 років, для пацієнтів як I, так і II груп. Відсутність больових відчуттів спостерігалась в основному в дітей II групи. Валідні шкали FLACC та VAS виявились практичними та надійними в оцінюванні вираженості післяопераційного болю. Оцінювання вираженості болю має вирішальне значення для оптимального управління болем у пацієнта та створення комфортних умов для нього в післяопераційний період. Залучення батьків до процесу оцінки вираженості болю $\epsilon$ важливим, оскільки сім'я $\epsilon$ незамінним джерелом підтримки для дітей з післяопераційним болем.

2. http://www.statisticssolutions.com/visual-analoguescale-vas/

Отримано 16.02.18 